\title{
The Allocation of Money in Couples: The End of Inequality? Allokation von Geld in Paarbeziehungen: Das Ende der Ungleichheit?
}

\author{
Wolfgang Ludwig-Mayerhofer* \\ Universität Siegen, Fachbereich 1, D-57068 Siegen \\ E-mail: ludwig-mayerhofer@soziologie.uni-siegen.de
}

\author{
Hermann Gartner, Jutta Allmendinger* \\ Institut für Arbeitsmarkt- und Berufsforschung der Bundesagentur für Arbeit, Regensburger Str. 104, D-90478 Nürnberg \\ E-mail: hermann.gartner@iab.de, jutta.allmendinger@iab.de
}

\begin{abstract}
Summary: Research conducted in the 1980s and early 1990s showed considerable inequalities within male-female couples as concerns financial arrangements and access to personal spending money. This paper provides an analysis of the allocation of money in German couples that goes beyond previous research in two respects. First, data are used that permit direct, albeit only rough, assessments of the amount of personal spending money available to each of the partners. Second, it is therefore possible to investigate in some detail the factors that may influence the availability of personal spending money and thus also the possible differences between the woman and the man concerning the amount of money available to each of them.

The empirical analysis is based on the German Low Income Panel (NIedrig-Einkommens-Panel, NIEP), a panel study representative of households with an income lower than about 1.5 times the German social assistance rate in 1999, the year of the first wave. We use the fourth wave of the NIEP, in which questions about couples' money management were added to the questionnaire. The data refer to those 718 households that consisted of an adult couple, with or without children.

While not all couples allocate the same amount of money to each partner, there is no difference in the proportion of men and women who have more money at their disposal than their partners. A number of hypotheses are tested concerning the amount of money allocated to individual partners, and the effects are basically the same for men and women. Investigation of the effects on the within-couple differences in personal spending money shows that the balance shifts in favor of the male partner if his education is superior to that of the female partner. This holds specifically for couples with very low incomes.
\end{abstract}

Zusammenfassung: Untersuchungen in den 1980er und frühen 1990er Jahren haben gezeigt, dass innerhalb von Paarbeziehungen eine beträchtliche Ungleichheit der Geldarrangements und beim Zugang zu Geld für persönliche Ausgaben besteht. Die hier vorgelegten Analysen der Allokation von Geld in Paarbeziehungen gehen in zweierlei Hinsicht über die bisherigen Untersuchungen hinaus: Erstens erlauben die hier verwendeten Daten eine direkte, wenn auch grobe, Einschätzung des Geldbetrages, der jedem Partner für die persönlichen Ausgaben zur Verfügung steht. Zweitens können wir detailliert die Faktoren bestimmen, die die Verfügung über Geld für persönliche Ausgaben und somit auch mögliche Unterschiede zwischen Männern und Frauen in der Verfügung über Geld beeinflussen.

Wir verwenden Daten des Niedrig-Einkommens-Panels (NIEP), einer repräsentativen Untersuchung von Haushalten, die in der ersten Panel-Welle im Jahr 1999 über ein Einkommen verfügten, das unter dem 1,5-fachen des damals gültigen Sozialhilfesatzes lag. In der unseren Auswertungen zugrunde liegenden vierten Welle waren einige Fragen zur Geldverwaltung enthalten. Unser Datensatz bezieht sich auf 718 Paarhaushalte mit und ohne Kinder.

In den meisten Paarbeziehungen können beide Partner über den gleichen Geldbetrag verfügen, und wenn das nicht der Fall ist, verfügen Männer genauso häufig wie Frauen über mehr Geld als der Partner. Eine Reihe von Hypothesen über die Geldzuteilung in Paarbeziehungen wird getestet. Die gefundenen Effekte sind bei Männern und Frauen im Wesentlichen die gleichen. Die Verfügung über Geld verschiebt sich zu Gunsten des Mannes, wenn dieser höher qualifiziert ist als die Frau. Besonders ausgeprägt ist dieser Zusammenhang in Haushalten mit sehr geringem Einkommen.

\footnotetext{
* We wish to express our gratitude to the anonymous referees and to the journal's editors for their critical comments on a first version of this paper, which helped us to improve both our arguments and their presentation. We are also indebted to Karen Scott-Leuteritz for her valuable help concerning correct usage of the English language.
}

\section{Inequality within families and couples}

During the past twenty years, sociologists and economists have begun to study within-household inequalities in the allocation of money. They have been attacking notions, prevailing in both disciplines, of 
families or couples ${ }^{1}$ as 'units' in which money is pooled and both partners (and possibly children) have equal or fair access to all resources or have common preferences about how money is to be spent (see, e.g. Becker 1981). Such assumptions are made implicitly in most research about inequality and poverty when the incomes of all household members are added up to create a 'household income'. After the appropriate adjustments for household size or composition not only is the income position of the household determined (such as being 'poor', or 'in the n-th quantile of the income distribution'), but it is also assumed that this income position is the same for all members of the household. Thus, if a household is poor, all household members are considered to be poor; if it is wealthy, wealth is attributed to every single person living in the household.

Such notions have been criticised for quite some time (see Young 1952, Jenkins 1991), but the critique has gained momentum through research that has investigated in more detail the money arrangements of couples. The seminal work by Jan Pahl (1983, 1989 ) is probably the most well-known, but similar research has been accomplished, for instance, by others in Great Britain (Wilson 1987, Burgoyne 1990), in Australia (Edwards 1982), New Zealand (Fleming 1997) and Sweden (Nyman 1999). ${ }^{2}$ These studies have investigated how the money that comes into the household is actually dealt with, that is, how it is allocated, managed, distributed and controlled. This research has demonstrated a num-

\footnotetext{
${ }^{1}$ We are keenly aware of the difference between 'households', 'couples' and 'families'. In this paper, we are interested in households that consist of (usually two) adults whose relationship is based on affective ties which in modern societies are normally termed 'love' or 'romance', no matter whether or not they are married or whether or not they have children. In Western societies such households constitute the vast majority of the private households that accommodate at least two adults.

${ }^{2}$ Other research has focused on the banking arrangements of couples (Cheal 1993, Treas 1993, Giesen/Kalmijn 1997). We do not discuss this research here as it is riddled with difficulties about assessing the actual management of accounts. Usually, if a couple has a joint account it is assumed that both have free and equal access to this account; if there are formally 'separate' or individual accounts, it is assumed that only the account holder has access to his or her own account. Whether such assumptions are justified is a matter of empirical assessment, but as yet the necessary information has not been collected. In addition, there seems to be no information to date concerning the amounts of money available to both or individual partners in bank accounts.
}

ber of inequalities between partners. For instance, it has been noted that cases in which women manage the household income occur most frequently in low-income households where managing money amounts to just another household chore, i.e. that of making ends meet. In contrast, male responsibility for money management occurs more frequently in more affluent working-class households and thus implies real decision-making power about the allocation of money (Pahl 1989). We may term such inequalities 'procedural' and contrast them with the inequalities of 'outcome' that occur if one of the partners has access to larger sums of money for his/her own personal spending ('personal spending money'). Nearly throughout, it has been reported that women tend to have less access to personal spending money and thus are more frequently in a disadvantaged position compared with men.

This paper, based on data collected recently in Germany, casts doubts on the persistence of 'outcome' inequalities, at least in this country. This is surprising as inequalities in labour force participation as well as income inequalities between men and women are rather pronounced in Germany (see Rubery/Fagan/Smith 1999, Employment in Europe 2004). Nonetheless, our data seem superior to most of the data used in earlier research as we have direct estimates, albeit rough ones, of the amounts of personal spending money available to the two partners. In addition, we use quite elaborate information about household income and expenditure and are thus able to check the plausibility of information about personal spending money. The fact that overall there are no gendered inequalities concerning the access to personal spending money does not imply, however, that inequalities between partners do not affect the allocation of money. What we note is rather that especially inequalities of education in lower class couples appear to influence the way that money is distributed between men and women.

\section{Previous research, aims of the present study, and hypotheses}

The most clear-cut statement about unequal access to money comes from Edwards' (1982) research in Australia. She claimed that in virtually all of the 50 couples she had investigated the men had access to more spending money than the women. The inequalities observed by Pahl in Britain are not as unequivocal, but nonetheless quite pronounced. 44 per cent of the men, but only 28 per cent of the 
women reported having personal spending money; 86 per cent of the men in contrast to 67 per cent of their partners spent money on leisure activities. In 17 cases (of 102 couples interviewed) the sums spent by the women on leisure activities exceeded those of the men, whereas the reverse was true in 55 cases (Pahl 1989: 148, see also Pahl 1990: 132). In addition, many more men reported spending money on drinking and gambling, and the sums spent on such activities are notoriously underestimated (Pahl 1989: 148). Differences between men and women concerning personal spending money were also observed in a large-scale standardized survey conducted in Britain in the late 1980s. Depending on the system of money management, between 18 and 42 per cent of the men were said to have more personal spending money, whereas the share of couples in which the female partner had more money was never higher than 20 per cent (Vogler/ Pahl 1994: 282, see also Pahl 1995: 372).

Even when couples 'pool' their money, this does not necessarily result in equal access to personal spending money according to previous research. For example, a study by Burgoyne and Lewis (1994) aimed at questioning the reality behind notions of income sharing. In their study of eight couples who were classified as having a shared management system, they found that wives reported reservations and inhibitions concerning access to money, and some claimed that they never spent money on themselves. This was in contrast to the men who used the joint account freely to draw personal spending money (similar results are reported by Singh [1997: 104] for Australian couples). Two explanations were offered for this finding: first, despite the idea of sharing in marriage, both women and men attached a sense of 'ownership' to earnings, which inhibited the spending of the money by the partner who did not 'own' it (see also Elizabeth 2001: 390). Second, even though both men and women were aware of, and valued positively, the wives' domestic labour as an important input to the household economy, it seemed that this work was not seen as entitling women to access to money in the same way as men's paid work in the formal economy did. Even though it is not clear how much money men and women spent on themselves, the results of this research were described as 'unequal financial outcomes' (Burgoyne/Lewis 1994: 112).

The only study that reports equal access of men and women to personal spending money comes from Sweden. Again based on large-scale survey data about Swedish households, 19 per cent of the women and 15 per cent of the men were said to have access to more money than their partners, whereas the remaining couples shared resources equally (Roman/Vogler 1999). This result was seen as pointing to the greater overall gender equality in Sweden. However, as the Swedish data were collected in 1996 (in contrast to 1987 as was the case with the British survey data) they may also be indicative of a secular trend towards more equality. ${ }^{3}$

One problem of the studies discussed is that the differences between men and women are often based on rough indicators. The best data available thus far seem to come from Pahl's qualitative research, whereas the survey data from which the more recent results stem are more superficial. They were not based on an assessment of the specific amount of money available to each partner, but rather on general indications as to whether the respondents felt that access to personal spending money was equal or not. Second, rather little is known about the causes of possible differences in access to personal spending money. Some analyses suggest that such differences are related to procedural dimensions of money in couples; according to Vogler and Pahl (1994), it is particularly the 'female whole-wage system' and the 'housekeeping-allowance system' of money management that is at the root of male predominance concerning personal spending money. But it might be assumed that there are other influences behind these results, such as differences in the partners' earnings or other forms of differences in power. Even though money arrangements are reported to depend at least partly on such factors

3 To the best of our knowledge, the present study is the first investigation of the allocation of money in couples in Germany. There is some research in Germany on the management of money by households (most notably Gräbe 1998), but this neglects the problem of money within households. Likewise, research on money and gender (Wrede 2003) has focused on (presumed) differences between women and men, but has not taken relationships within couples into account (with the exception of women running into debt because of their standing surety for loans their partners had taken out, see Schmedt 2003). Ludwig-Mayerhofer (2000) has analysed money management in German couples employing the ISSP (International Social Survey Programme) data from 1994. Results from recent qualitative research on money within couples that focuses on the question as to the extent to which money is seen as 'common' or as 'money of one's own' can be found in Wimbauer et al. (2002); Wimbauer (2003); Allmendinger et al. (2004); and Schneider et al. (2005). Finally, research should be mentioned that deals with the experiences of monetary crises over three generations (Heisterhagen/ Hoffmann 2003) or with the ways that parents teach their children to deal with money (Rosendorfer 2000). 
(Pahl 1989), as yet no detailed analyses of the possible influences of relative power or other factors on the availability of personal spending money have been conducted.

Therefore, more research on the allocation of money in couples and personal spending money must be welcome. We provide an analysis that goes beyond previous research in two respects: first, as outlined above, data are used that permit direct, albeit only rough, assessments of the amount of personal spending money available to each of the partners. Second, we are therefore able to investigate in some detail the factors that may influence the availability of personal spending money and thus also possible differences between women and men concerning the amounts of money available to them.

What hypotheses can be formulated to explain the access to personal spending money of women and men in couples? We first discuss some hypotheses that concern the allocation of money per se, in other words, hypotheses that are not related to inequalities between the partners. The allocation of 'individual money' may be restricted by a number of factors. First, the availability of enough money, i.e. a sufficiently high income, is a prerequisite for personal spending money; the more scarce money is, the more the necessity of controlling the flows of money coming in and going out may work against individual money. Along the same line, couples with children may more frequently see a need to restrict individual spending as opposed to couples without children, and this need should increase with the number of children. Second, some people may see individual money as incompatible with the idea of 'being a couple'; we may assume that this is more frequently the case with married couples as opposed to cohabiting couples (the latter tend more frequently to manage money separately, see Fleming 1997, Ludwig-Mayerhofer 2000, Vogler 2005), but also with older couples, who might more frequently adhere to notions of a couple as a social unit where there is little room for individual needs. Third, earlier research based on the International Social Survey Programme data from 1994 showed that couples in eastern Germany tend more to manage money jointly (Ludwig-Mayerhofer 2000, Wimbauer et al. 2002); this may also work against allocating individual spending money.

Thus far, we have considered to what extent money may or may not be allocated to the individual partners, but we have not discussed inequality within the couple. The resource theory of power connects such inequalities mainly to the ratio of individual incomes (see the seminal study by Blood/Wolfe
[1960]). According to this theory we would expect that the more money one partner brings into the relationship as compared with the other, the more power he or she has (see Vogler 1998 for discussion), and this may also concern the power to spend money individually (see Blumstein/Schwartz 1985: 53). We should add that a possible relationship between the partners' income ratio and inequality concerning personal spending money may be explained by other theories as well. The findings discussed above that especially women seem to think that money, even though shared in principle, actually 'belongs' to the partner who has earned it indicates that notions of justice, i.e. normative beliefs, may likewise be a cause of unequal allocation of money. While it may be argued that such beliefs constitute just another form of power, it would be desirable to distinguish between different kinds of power. However, the data employed in our analysis do not permit taking this distinction into consideration.

Returning to the resource theory of power, we may note that other inequalities between partners might also influence the relative power of one partner, most notably education. Certainly, education has a material dimension, which is well captured by the amount of money each partner contributes to the household income. But in addition, education and vocational training indicate income potential; ultimately, they might well come along with societal recognition. The difference in the educational achievements of the two partners might thus be related to the amount of personal spending money favouring the person who has more education. Finally, we might consider the age difference between the partners. The younger one partner is in relation to the other, the better his or her exit options and therefore the larger his or her share of personal spending money might be.

The resource theory of power is often contrasted with theories of doing gender or, perhaps more appropriately, of the symbolic display of gender (Brines 1993). Indeed, observations have been made in small-scale studies of money management in couples that may be interpreted in the light of such theories. In her study of cross-class families in which wives' earnings were superior to those of their husbands, McRae (1987) reported that most couples used a system of joint money management, possibly to smooth the actual inequality concerning income; and Stamp's (1985) study of breadwinning wives concluded that the wives tried to avoid exerting too much power because of cultural norms according to which women should not be more powerful than men. In the same vein, Potuchek 
(1997) noted that even when women were earning as much as their partners, they still declared their partner as the main breadwinner. From this point of view, a husband with higher earnings should also have more personal spending money than his wife, whereas one would not expect a similar shift in favour of wives who earn more than their husbands; the possibility might rather be considered that men whose partners earn more even have comparatively larger sums of personal spending money at their disposal in order to compensate for their lack of income or to make this lack invisible. Similar hypotheses may be formed with respect to education: men with higher education than their partners might take advantage of this fact, whereas women whose education is superior to that of their partners might be tempted to 'hide' their superior status.

Some research suggests that money arrangements are influenced by gender stereotypes (Vogler/Pahl 1993, Treas 1993). While our data do not permit the testing of such effects directly, we might employ some proxy variables. For instance, gender stereotypes are related to age (not necessarily due to the process of ageing but rather because of cohort effects), and therefore the balance might be expected to be shifted more in favour of men in older couples. Likewise, education might affect notions of inequality or equality in intimate relationships, with more highly educated persons being more likely to overcome stereotyped notions of gender (Baxter/ Kane 1995: 206, Hayes/McAllister/Studlar 2000: 435).

A final set of hypotheses is derived from the fact to which we will return immediately - that our sample is comprised largely of medium and low income households. On the one hand, scarcity of money may restrict personal spending money for both partners, as we have already outlined. On the other hand, previous research suggests that it is precisely in low income couples that unequal distribution of personal spending money occurs. For instance, Pahl $(1983,1989)$ reports that in such couples money arrangements such as the 'whole wage (or wife management) system' are more prevalent, and this system (in spite of its name) often implies the husband keeping some pocket money before handing the remainder of his wage to the wife or female partner. The latter has to struggle to make ends meet with the money she receives and often experiences no leeway to spend money on her own needs. To test the hypothesis of differences in personal spending money especially in low income couples, we divide our sample according to income.

\section{Data and methods}

The German Low Income Panel (NIedrig-Einkommens-Panel, NIEP) was started in 1999 to gain insight into the development of income and living conditions of low income households. It includes households whose income was lower than about 1.5 times the German social assistance rate in the first wave. The Panel was conducted as a computerassisted telephone interviewing survey in which one household member was questioned in detail about his own income situation as well as that of all other household members. Data were collected twice a year until 2002. The first wave contains 1922 households and represents 5.6 million or 14.8 per cent of all households in Germany.

We use data from the fourth wave of the NIEP, collected in 2001, in which a few questions about couples' money management were added to the questionnaire. In this wave 1417 households from the initial sample were still participating, and 718 of these households consisted of an adult couple, with or without children. In some cases, other adults were also living in the household, but the questions about money management clearly focused on the respondent and his or her partner. Because of some missing values the maximum number of couples available for our analyses is reduced to 713 .

Due to the sampling frame, in the first wave all households had an income below the 'low income threshold' as defined above. By the fourth wave, a sizable number of households had increased their income, mostly because individuals who had been unemployed or in training in the first wave had found gainful employment 18 months later. More precisely, 41 per cent of the households whose data are used here (that is, all households with at least one adult couple) had increased their income above the 'low income threshold', and 92 per cent of them had an income above the social assistance level, which can be interpreted as the German poverty line.

To give a better indication of the degree to which our sample matches German households in general, we compared the income distribution of our sample (in the fourth wave) with that of a representative sample of German households from the year 2001, the Socioeconomic Panel (see SOEP Group 2001). ${ }^{4}$

\footnotetext{
${ }^{4}$ It should be noted that the sampling frame of the two samples is slightly different. The NIEP sample included only households in which the informant spoke German sufficiently well to participate, but apart from that no restrictions were made concerning nationality or resident
} 
In spite of the increase in income, the income distribution in our sample exhibits values considerably below those of the 'average' German household with at least one adult couple (Table 1).

The mean equivalence income ${ }^{5}$ of the NIEP sample is roughly two thirds of the one we find in the SOEP data. The $25^{\text {th }}$ percentile of the NIEP sample has an equivalence income that is slightly below that of the $10^{\text {th }}$ percentile of the SOEP data; and the $90^{\text {th }}$ percentile of the NIEP sample is close to the median of the SOEP. Obviously, in spite of some income increases in many couples, and even a considerable increase in a small number of couples (see the value of the $99^{\text {th }}$ as compared with the $90^{\text {th }}$ percentile), our sample still represents mainly couples from the lower half of the general income distribution; the standard deviations of the means of both samples (NIEP: about one third of the mean; SOEP: about half of the mean) also make it very clear that especially the wealthier couples are largely absent from the NIEP sample. For this reason, our analysis has to be restricted to differences between medium and low income couples. As outlined at the end of the previous section, we not only report results on all couples in the NIEP sample but also divide the sample at the $25^{\text {th }}$ percentile of the equivalence income (roughly equivalent to the $10^{\text {th }}$ percentile of the SOEP sample, which is more representative of the population in general). This makes it possible to test the hypothesis of unequal access to personal spending money specifically in couples with very low incomes.

In the following, we focus on the question about 'personal spending money'. Each respondent who had a partner (whether married or not) was asked whether he or she regularly had money at his or her disposal to use freely without being accountable to anybody for it. ${ }^{6}$ The question was then repeated with respect to the partner's personal spending mon-

status. The SOEP in contrast includes, in addition to German-born citizens, (overweighted) samples from five important immigrant groups with non-German citizenship and a sample of immigrants of German origin from Eastern Europe (mostly Russia and Poland) who by law acquire German citizenship when coming to Germany. The SOEP data reported here uses weights that are intended to make the data representative of the target population.

5 The equivalence income was computed according to the 'new' OECD scale which assigns a weight of 1 to the head of the household, 0.5 to persons aged 15 and older and 0.3 to persons under 15 years old.

6 'Verfügen Sie selbst regelmäßig über Geld, mit dem Sie machen können, was Sie wollen, ohne jemandem Rechenschaft ablegen zu müssen?' "Do you regularly have money ey. Respondents had to classify the sums available to each partner per month according to the following categories:

- No personal spending money

- Below DM 50 (about $€ 25.5$ )

- DM 50 to less than DM 100 (€51)

- DM 100 up to less than DM 250 (€ 127.6)

- DM 250 up to less than DM 500 (€ 255.3)

- DM 500 or more.

On the basis of these data, we can compare the amount of personal spending money of each partner and thus arrive at an assessment of who has more money which seems superior to previous estimates that were based on answers to questions such as 'who in your household would you say has the most personal spending money, the male partner, the female partner or both equally' (see Roman/ Vogler 1999: 435, note 17). In addition to this, we were able to check the plausibility of the data. For this purpose, we subtracted from the overall household income fixed expenses, i.e. the rent and other expenses for the flat or house as well as mortgage payments and payments for other bank loans. Next, we subtracted the personal spending money of both partners. Here the theoretical mean value for each category was inserted (e.g. DM 25 for the category 'below DM 50'), with the exception of the highest category, where the lowest possible value (DM 500) was used. We call the resulting amount the net disposable income, which, despite the minor error that might result from employing approximate values for personal spending money, should be sufficiently large to cover the typical expenditure on food and other daily needs. ${ }^{7}$

For one per cent of the households the net disposable income is less then zero. In 95 per cent of the cases the net disposable income is $€ 700$ or more. If we relate disposable income to household size and composition (in analogy with the 'new' OECD equivalence scale for household income, see footnote 6), 95 per cent have a 'net disposable equivalence income' of $€ 360$ or more. Such sums can be

at your disposal with which you may do whatever you wish without having to account to someone for it?"

7 We should mention that in this calculation we are actually assuming that there is something like a 'household income' - in contrast to two separate incomes, for instance. However, some kind of sharing seems to take place in many couples, even though it is not necessarily equal sharing. As we do not have any clues about couples' actual money arrangements, we use what is most likely the 'modal' arrangement of couples as a starting point. 
Table 1 Income distribution of NIEP and SOEP samples

\begin{tabular}{|c|c|c|c|c|c|}
\hline & & \multicolumn{2}{|c|}{ NIEP } & \multicolumn{2}{|c|}{ SOEP } \\
\hline & & $\begin{array}{l}\text { Net household } \\
\text { income }\end{array}$ & $\begin{array}{l}\text { Equivalence income } \\
\text { (OECD, new) }\end{array}$ & $\begin{array}{l}\text { Net household } \\
\text { income }\end{array}$ & $\begin{array}{l}\text { Equivalence income } \\
\text { (OECD, new) }\end{array}$ \\
\hline Mean & & 3739 & 1857 & 4952 & 2757 \\
\hline S.D. & & 1273 & 587 & 2427 & 1408 \\
\hline \multirow[t]{7}{*}{ Percentiles } & 1 & 1400 & 739 & 1600 & 850 \\
\hline & 10 & 2229 & 1249 & 2631 & 1522 \\
\hline & 25 & 2736 & 1500 & 3500 & 1920 \\
\hline & 50 & 3674 & 1781 & 4500 & 2444 \\
\hline & 75 & 4513 & 2123 & 6000 & 3333 \\
\hline & 90 & 5372 & 2483 & 8000 & 4333 \\
\hline & 99 & 7479 & 4183 & 13500 & 7500 \\
\hline
\end{tabular}

Source: NIEP wave 4, own calculations; GSOEP, 2001 wave, own calculations

All values are in Deutsche Mark (DM)

regarded as plausible as they are above the level of social assistance payments, which are supposed to cover individuals' basic needs and render possible participation in cultural and social life. Net disposable equivalence income below this level does not necessarily imply that the data on personal spending money are implausible; there may be other reasons such as erroneous data about income or about other types of expenditure. However, in order to be sure we conducted all of the analyses twice, once including all couples and once excluding the five per cent with a net disposable equivalence income below $€ 360$. The results we obtained were almost always in agreement with those for the full sample, and so we report only the latter results in the following, indicating any deviations that occurred in the reduced sample.

However, plausibility cannot be equated with validity. At the very least, one might presume that the data may be affected by respondent bias. Is there anything we can say about this? ${ }^{8}$ We have only indirect clues, which amount to the conclusion that respondent bias may play less of a role here than concerning other aspects of the financial organisation of households. In all our models, we include a variable indicating which of the partners - male or female - has provided the answers to the interviewer. The reason for this procedure is that with regard to another question - 'which of the two of you has the final say in financial matters' - the data

\footnotetext{
${ }^{8}$ We may note in passing that previous research - not least the research we discussed above - did not at all address questions of the plausibility or validity of their data.
}

are influenced heavily by the respondent's gender: whereas 12 per cent of the men attributed the 'final say' to themselves and 7 per cent to their wives or partners (with all others indicating that both partners had an equal influence), only 5 per cent of the women said that their partners had the final say and 24 per cent claimed the final say for themselves. This strong difference was also observed in multivariate models in which this variable was regressed on a number of factors that might actually influence decision-making power, which indicates that the answers to this question are heavily biased by the respondents' gender and therefore of little value. ${ }^{9}$ However, no such influence of respondent gender was obtained when the variable 'personal spending money' was investigated, neither in bivariate nor in multivariate analyses.

\section{Results}

\section{Personal spending money of men and women: descriptive analyses}

In 35 per cent of couples neither of the partners has any personal spending money at his or her disposal, in 55 per cent both partners do. The remaining couples report that either the man or the woman has personal spending money, each group comprising 5 per cent (Table 2). As expected the distribution differs according to the income level of the couples.

\footnotetext{
${ }^{9}$ Of course, research may address the sources of such respondent bias. However, the data we use here do not permit such analyses.
} 
Table 2 Amount of personal spending money of men and women, in DM (first row: absolute frequencies; second row [italics]: total percent)

\begin{tabular}{|c|c|c|c|c|c|c|c|}
\hline \multicolumn{8}{|c|}{ Female Partner } \\
\hline Male Partner & None & $<50$ & 50 to 99 & 100 to 249 & 250 to 499 & $500+$ & $\mathbf{N}$ \\
\hline \multirow[t]{2}{*}{ None } & 250 & 8 & 6 & 13 & 4 & 4 & 285 \\
\hline & 35 & 1 & 1 & 2 & 1 & 1 & 40 \\
\hline \multirow[t]{2}{*}{ less than 50} & 7 & 25 & 5 & 1 & 0 & 0 & 38 \\
\hline & 1 & 4 & 1 & 0 & 0 & 0 & 5 \\
\hline \multirow[t]{2}{*}{50 to 99} & 5 & 4 & 71 & 20 & 1 & 0 & 101 \\
\hline & 1 & 1 & 10 & 3 & 0 & 0 & 14 \\
\hline \multirow[t]{2}{*}{100 to 249} & 22 & 3 & 14 & 146 & 10 & 4 & 199 \\
\hline & 3 & 0 & 2 & 21 & 1 & 1 & 28 \\
\hline \multirow[t]{2}{*}{250 to 499} & 1 & 2 & 2 & 9 & 36 & 4 & 54 \\
\hline & 0 & 0 & 0 & 1 & 5 & 1 & 8 \\
\hline \multirow[t]{2}{*}{500 or more } & 1 & 0 & 3 & 2 & 5 & 20 & 31 \\
\hline & 0 & 0 & 0 & 0 & 1 & 3 & 4 \\
\hline \multirow[t]{2}{*}{ N } & 286 & 42 & 101 & 191 & 56 & 32 & 708 \\
\hline & 40 & 6 & 14 & 27 & 8 & 5 & 100 \\
\hline
\end{tabular}

Source: NIEP wave 4, own calculations

48 per cent of the couples at the very bottom of the income distribution (lower 25 per cent) ${ }^{10}$ report having no personal spending money at all, while this holds for only 31 per cent of the couples in the upper 75 per cent. Gender differences cannot be observed in either of the income groups, however. This also holds for the amount of money that men and women have at their own disposal. The marginal distribution of men's and women's personal spending money is virtually the same. Again, this applies to the 'very low income' couples (bottom 25 per cent) and to the couples in the 'not so low' part of the income distribution, even though in the latter couples the amount of money available for each partner is clearly more frequently in the higher range and considerably fewer women and men are reported to have no personal spending money at all.

This finding does not imply that within each couple both partners command the same amount of money. As expected there are some inequalities within couples, but overall they are not in favour of one gender over the other. Instead, 12 per cent of both

10 The bottom 25 per cent were defined by the value of the $25^{\text {th }}$ percentile of the distribution of the equivalence income. At this value (DM 1500) three couples were observed, and thus our 'lower 25 per cent' actually comprise not only 178 couples, but one additional couple with the same income as the $178^{\text {th }}$ couple. the male and the female partners, respectively, have more money available for individual use than their partners. Again, we cannot assume more or less inequality within 'very low income couples', as the small deviation from this distribution which we observe in these couples (11 per cent of the female and 7 per cent of the male partners command larger sums than their partner) are clearly not significant (neither statistically nor substantially). We might also note that the marginally larger share of couples in the 'lower 25 per cent' group in which both partners command the same amount of money (82 per cent) is a result of more couples in which both partners have no money at all at their individual disposal.

\section{Multivariate analyses}

In order to assess the factors that may determine the amount of personal spending money and the difference between women and men, ordered logistic regression models were estimated. A first set of models focused on the personal spending money of men and of women separately. These models help us to understand whether or not the amount of personal spending money is influenced by the same factors (and to the same degree) in the case of men and of women. In addition, models were estimated that used the difference in personal spending money as a dependent variable. These models might give a 
clearer picture of factors that work differently for male and for female partners.

Before proceeding, some variables used in the following analyses have to be described in more detail.

Dependent variables: The amount of personal spending money for men and women was used 'as is'. The difference between men and women had to be recoded due to the very thin marginal distribution of the resulting variable, particularly if the sample was divided into the income categories (lower 25 and top 75 per cent). If the personal spending money of one partner is two or more categories higher than that of the other partner (e.g. one partner was in category 250 to 499 and the other in category 50 to 99 or even lower), we say that this partner has 'much more' money; if the distance between both partners is one category only, we say that he or she has 'some more'. Thus, the variable 'difference in personal spending money' has five categories, ranging from 'female partner has much more' (lowest category) to 'male partner has much more' (highest category).

Income: To make household income comparable between households of different size and composition, incomes were weighted using the new OECD equivalence scale (see footnote 6). As couples have to bear widely different costs for their flats or houses and these costs necessarily restrict the amounts of money available for other purposes, we deducted all costs related to the flat prior to computing the weighted incomes. Likewise, any payments made to people outside the household were deducted, as in most cases such payments are mandatory (such as maintenance for children living in a separate household) and thus restrict the disposable income additionally. ${ }^{11}$

Income ratio of partners: The bargaining power within the household rises only with the outside option income (Nash 1950). Therefore, to compute the personal income we excluded welfare transfers targeted at the whole family (such as child and housing benefits), even if one partner had named them among his own resources. The income ratio is calculated as

(male personal incomel(female personal income +1)) if the male income is higher and

$-($ female personal incomel(male personal income +1$))$

${ }^{11}$ We also ran analyses using (weighted) household income 'as is', but as expected the variable described above yielded the most clear-cut results. otherwise. In order to test for effects of 'gender display', this variable was used not only 'as is' - which would indicate an effect along the lines of the resource theory of power - but also in two additional ways: first, to test for a curvilinear effect the income ratio was squared and used together with the simple income ratio. ${ }^{12}$ Second, the income ratio was truncated from the bottom at the value of zero which means that the value of zero was assigned to couples in which the woman's income was higher than that of her husband or partner.

Labour market participation: As labour market participation (male only/female only/both/neither) is highly correlated with income ratio, it was meaningless to estimate models including both variables due to collinearity. However, all models were run again with labour market participation variables instead of the income ratio. The results were virtually unchanged, and we therefore report only the models including the income ratio.

Education: As with other variables, both the education of the individual partners and the difference between the two partners may be important. ${ }^{13}$ Including both partners' education plus the difference in education must result in extreme collinearity and therefore only the education of the male partner and the difference in the education of the two partners was used. However, owing to the difference in education being included in the model, 'education of the male partner' must be read as 'educational level of both partners, unless there is a difference in education'. As education is measured at an ordinal level only, all education measures are represented by dummy variables. Note that our variable 'education' concerns not only schooling, but also training for the labour market; a person who has undergone vocational training (below university level), even if s/he has only completed lower secondary education usually has a higher earnings potential than a person with intermediate secondary education (e.g. an intermediate school leaving certificate, such as Ger-

${ }^{12}$ For this purpose, the minimum value of the income ratio was set to zero before taking the square.

13 We should emphasise that the sample comprises a considerable number of persons who are in vocational training (including university studies), unemployed or retired and hence without any earnings from paid work. Therefore, at the individual level the relationship between income and education is rather weak. Likewise, there is almost no correlation between education and the household income. This is the case because particularly among the well educated couples of this sample a substantial number can be found in which only one partner is employed and the other is either unemployed or pursuing further education. 
Table 3 Factors determining the amount of personal spending money of men and women (ordered logistic regression models)

\begin{tabular}{|c|c|c|c|c|}
\hline & \multicolumn{2}{|c|}{ Men } & \multicolumn{2}{|c|}{ Women } \\
\hline & Coeff. & S.E. & Coeff. & S.E. \\
\hline Income (/1000) & .962 & $.132^{\bullet}$ & .944 & $.131^{\bullet}$ \\
\hline Age (male partner) & -.020 & $.008^{\circ}$ & -.021 & $.008^{\otimes}$ \\
\hline Married & -.537 & $.228^{\circ}$ & -.474 & $.228^{\circ}$ \\
\hline Number of children & -.136 & .079 & -.070 & .079 \\
\hline Eastern Germany & -.503 & $.164^{\otimes}$ & -.516 & $.164^{\otimes}$ \\
\hline Income ratio (male/female) & .006 & .052 & -.003 & .052 \\
\hline Age difference & .022 & .016 & .031 & .016 \\
\hline Education: 'Abitur' or university degree $\mathrm{e}^{(\mathrm{a})}$ & .307 & .299 & .815 & $.300^{\otimes}$ \\
\hline Education: Vocational training ${ }^{(a)}$ & .053 & .198 & .335 & .199 \\
\hline Difference in education: Male higher ${ }^{(b)}$ & -.138 & .209 & -.514 & $.212^{\circ}$ \\
\hline Difference in education: Female higher ${ }^{(b)}$ & -.132 & .263 & .123 & .263 \\
\hline Respondent: Female & .237 & .147 & .103 & .147 \\
\hline -2 Log-Likelihood Null Model & 2090.49 & & 2114.96 & \\
\hline -2 Log-Likelihood Final Model & 1991.21 & & 2006.38 & \\
\hline$\chi^{2}$ & $99.28^{\bullet}$ & & $108.58^{\bullet}$ & \\
\hline McFadden's Pseudo- $R^{2}$ & .047 & & .051 & \\
\hline
\end{tabular}

${ }^{0} p<0.05,{ }^{\otimes} p<0.01,{ }^{\bullet} p<0.001$ Significance levels according to t-statistic (Coeff./S.E.)

(a) Reference category: Lower or intermediate secondary education only (Hauptschule or Mittlere Reife), no vocational training

(b) Reference category: Both equal

Source: NIEP, wave 4, own calculations

many's 'Mittlere Reife' or Britain's GCSEs) but no vocational training. Therefore we code persons with only lower or intermediate secondary education as 'low educational level', those with a vocational qualification as 'medium' and those with completed upper secondary education (e.g. the German 'Abitur', which entitles its holder to enter university) or with a university degree as 'high'.

Age and age difference: Only the age of the male partner is included in our analyses, as the age difference is also built into our multivariate models. The age difference was computed as (male age female age) and ranges from -22 to 34 .

Let us first turn to factors determining the amount of personal spending money of men and women (Table 3). Overall, most of the results are in line with some of the hypotheses presented above. The personal spending money of both men and women depends highly on the income level of the household. Surprisingly, however, the number of children has no significant impact on the amount of personal spending money, a result that applies in particular to women. ${ }^{14}$ According to the second set of

${ }^{14}$ We would hypothesize that the number of children is hypotheses, some couples were assumed to be less inclined to allocate individual spending money. Indeed, compared with unmarried couples, both married men and married women have less personal spending money at their disposal. Likewise, we assumed a negative correlation between age and personal spending money since older couples may adhere to notions of the couple as a 'unity' more strongly than younger couples do. Results show that this applies to women in particular. Finally, we focused on East-West differences. Prior research showed that couples in eastern Germany tend more to manage money jointly, a result that is strongly supported by the data used here. Regardless of their total income, eastern German men and women living as couples have considerably less personal spending money.

Further hypotheses were related to factors affecting the internal balance of power within couples. First,

indeed important here, as with an increasing number of children the restrictions on parents' spending money should increase as well. We also tested models where only a dummy variable was included that indicated the presence or absence of children. The results did not differ at all from those we present here. 
the resource theory of power states that the more money one partner brings into the relationship as compared with the other, the more power he or she has. In turn, we should find significant effects of the income ratio on the amount of personal spending money. According to our analyses this is not the case, however. For both men and women the personal spending money is unaffected by the income share they contribute to the household. Alternative versions of the variable income ratio (including its square) which should test 'gender display' effects - in other words, the assumption that the income ratio works differently when the female partner has the higher income - also exhibited no effect. ${ }^{15}$ Equally, the age difference between the partners does not exert the expected impact on personal spending money, quite in contrast to the educational level and the difference in the partners' education. First, the educational level of the couple has a clear impact on the woman's personal spending money. Couples with a high school / upper secondary school qualification or a university degree allow the female partner more personal money compared with couples with lower educational achievements. It seems to be the case that highly educated couples share different norms of justice from couples with low education only, and further a redistribution of personal spending money in favour of women.

Analysing the difference between men and women as regards educational and vocational levels, we find that an educational or vocational advantage of men over their partners translates into less personal spending money for the women (but not vice versa). This result is in line with theories of the symbolic display of gender as outlined above. While men use their education as a powerful resource to obtain more personal money, women may indeed hide their educational advantage by allocating more personal spending money to their partners as opposed to themselves. In addition, social class assumes a specific role. As further analyses (not shown here) indicate, the men who take advantage of their higher education are particularly those who have completed vocational training while the wife or partner has a low school qualification at best. It is in this low education class constellation that men

${ }^{15}$ When both the income ratio and its square were tested, neither of the variables were significant (which might be expected due to high collinearity) and the log-likelihood of the model increased only marginally. Similarly, the truncated variable produced neither a significant effect nor an improvement of the log-likelihood. These results are not included in our tables, but they are available upon request from the authors. increase their personal money at the expense of their partners.

In a further step, regression models were run separately for couples with relatively low (lower $25 \%$ ) and higher (upper $75 \%$ ) household incomes. The results for the more advantaged group are in line with the overall results presented in Table 3. In contrast, an analysis of the very poor couples shows some differences. In particular, overall household income does not affect personal spending money, which may be explained by the very low income variation in this group. However, all the effects of the educational and vocational level attained also show in this group.

In the final step of our analysis we now regress the variables introduced above on the difference in personal spending money (Table 4). As might be expected from the similarity between the factors influencing the amount of personal spending money of male and female partners, very few factors could be found that have an effect on the difference in personal spending money. What is most conspicuous is the absence of any influence of the difference in individual income. However, the same result was obtained when labour market participation was used; whether neither partner, one partner or both partners were in paid work made no difference concerning personal spending money when household income was taken into account. ${ }^{16}$ Likewise, the age difference between partners had no influence. ${ }^{17}$ In couples with higher education only a slight and non-significant tendency working in favour of the female partner's personal spending money can be observed. (In the models that excluded the five per cent of the couples with implausible data on income or expenditure the educational variables also became significant at the 5 per cent level.) In terms of differences between the two partners as regards educational attainment the results are in line with the results reported above. Men can translate their higher education into more personal spending money while resource theory does not work for women, presumably due to the symbolic display of gender in particular in the low education class.

16 It even made no difference when household income was not taken into account. The lack of a relationship between labour market participation and personal spending money was a persistent finding both of bivariate and several multivariate analyses.

${ }^{17}$ As it might be assumed that only large differences in age are important, we also tried models in which the age difference was included as a series of dummy variables. However, no effect of the age difference was observed. 
Table 4 Factors determining the difference in the personal spending money of men and women (ordered logistic regression model; positive coefficients indicate that the variable works in favour of the male partner)

\begin{tabular}{|c|c|c|c|c|c|c|}
\hline & \multicolumn{2}{|c|}{ All couples } & \multicolumn{2}{|c|}{ Lower $25 \%$} & \multicolumn{2}{|c|}{ Upper $75 \%$} \\
\hline & Coeff. & S.E. & Coeff. & S.E. & Coeff. & S.E. \\
\hline Income (/1000) & .152 & .160 & -.226 & .676 & .066 & .200 \\
\hline Age (male partner) & .005 & .010 & -.014 & .021 & .011 & .011 \\
\hline Married & -.120 & .298 & .450 & .656 & -.300 & .336 \\
\hline Number of children & -.058 & .102 & -.032 & .230 & -.075 & .116 \\
\hline Eastern Germany & -.053 & .209 & .025 & .459 & -.038 & .242 \\
\hline Income ratio (male/female) & .061 & .067 & .338 & .179 & .034 & .073 \\
\hline Age difference & -.010 & .020 & .025 & .051 & -.020 & .022 \\
\hline Education: 'Abitur' or university degree(a) & -.688 & .387 & -.293 & .843 & -.792 & .448 \\
\hline Education: Vocational training ${ }^{(a)}$ & -.453 & .257 & -.392 & .610 & -.489 & .286 \\
\hline Difference in education: Male higher ${ }^{(b)}$ & .698 & $.266^{\otimes}$ & 1.662 & $.608^{\otimes}$ & .450 & .303 \\
\hline Difference in education: Female higher ${ }^{(b)}$ & -.519 & .338 & -.457 & .822 & -.515 & .375 \\
\hline Respondent: Female & .257 & .189 & .601 & .410 & .186 & .216 \\
\hline -2 Log-Likelihood Null Model & 1183.13 & & 256.91 & & 977.07 & \\
\hline -2 Log-Likelihood Final Model & 1167.10 & & 241.39 & & 963.80 & \\
\hline$\chi^{2}$ & 16.03 & & 15.52 & & 13.27 & \\
\hline McFadden's Pseudo- $R^{2}$ & 0.014 & & 0.060 & & 0.014 & \\
\hline
\end{tabular}

${ }^{\otimes} \mathrm{p}<0.01$ Significance levels according to t-statistic (Coeff./S.E.)

(a) Reference category: Lower or intermediate secondary education only (Hauptschule or Mittlere Reife), no vocational training

(b) Reference category: Both equal

Source: NIEP wave 4, own calculations

Repeating the analysis both in the 'lower 25 per cent' and the 'upper 75 per cent' couples, we see that the effect of the difference in education is at work basically in the lower 25 per cent of the sample. In the 'upper 75 per cent', we cannot discern any effect, even though we might note that the effect of the highest level of education (upper secondary school leaving certificate or university degree) working in favour of more female personal spending money, is approaching significance. In the lowest income quarter of the sample, the effect of high education is much weaker and far from significant; but the effect of the difference in education is very pronounced and in addition the male-female income ratio is approaching significance. ${ }^{18}$ Overall, these results thus suggest that it is the lowest income couples in which inequalities in personal spending money might make themselves felt. This is not because inequality per se is more pronounced in these couples; it is more the case that we were

18 The inclusion of the income ratio squared again provided no relevant improvement of the model fit, and the significance of the truncated variable was marginally lower than that of the income ratio 'as is'. able to discern tendencies, albeit slight, towards more overall equality due to the financial restrictions according to which no personal spending money at all is allocated to either partner in a larger percentage of couples. 'More inequality' in these lower income couples means more that differences between the partners as regards education (and perhaps also regarding income) shift the balance between the partners, something that we do not observe in the 'upper 75 per cent' couples. We might add that this result in the 'lower 25 per cent' couples is not due to the possible inaccuracies we observe in a small number of couples. Rather, the effects we have reported here become even slightly more pronounced when the five per cent of the couples with implausible data are excluded, with the influence of the male-female income ratio also becoming statistically significant at the 5 per cent level (results not shown). ${ }^{19}$

19 Again, inclusion of the income ratio squared resulted in both variables - income ratio and its square - not being significant and yielding no improvement of the model fit. The truncated variable, which would indicate that the income ratio works only in favour of the male but not of the 


\section{Discussion and conclusion}

In contrast to most previous research the study presented above does not support the notion that gender generally has an influence on the overall distribution of personal spending money in couples; most of the couples allocate roughly the same amount to each partner and the number of couples in which the men have more money is counterbalanced by about the same number of couples where the reverse is true. The results indicate a degree of equality that is even slightly larger than that found in a Swedish sample in 1996. However, it should be noted that in this study a sample of couples with rather low incomes was used, and the lower the overall income of a couple, the more equality is observed not least due to those couples in which neither of the partners commands any personal spending money. Therefore, we cannot rule out the possibility that in wealthier couples more inequality might be observed. We must also bear in mind that the question used in this survey to gain insight into couples' allocation of money differed from earlier studies; perhaps this also accounts for (some of) the deviation of our results from earlier research. Still, the relatively large equality in personal spending money could also be due to a secular, albeit slow, trend towards more gender equality. It is true that such equality is not making itself felt so much in the private sphere concerning domestic work (e.g. Bianchi et al. 2000); the little equality that seems to be evolving does not arise from men doing more but from women doing less housework. But one might speculate that this is precisely what could explain the increasing equality in women's access to personal spending money; perhaps men 'buy' themselves out of domestic work by conceding to women equal access to financial resources. ${ }^{20}$

female partner, was significant at the 5 per cent level, and the log-likelihood was marginally, but not significantly, higher than that of the model with income ratio 'as is'. Therefore we cannot exclude the possibility that there is some truth to the 'gender display' hypothesis also with respect to income in these very low income couples, but we cannot judge which theory is better in terms of explanatory power.

${ }^{20}$ It might be argued that the equality in personal spending money that we have observed actually hides the fact that women have to spend some of this money on buying domestic services. We think this is very unlikely. First of all, the way the question concerning personal spending money was phrased does not leave much room for such interpretation. Second, Germans are comparatively reluctant to buy domestic services and those who are not re-
A second finding concerns the factors operating within our sample towards more or less equality of personal spending money. Surprisingly, few factors shift the balance more towards men or women; but the influences are more pronounced in couples with very low incomes. Here, we notice that higher education on the part of the man, but also a higher male/ female income ratio, may shift the balance more towards the male partner. This finding is in line with resource theory on the part of the men as well as the symbolic display of gender on the part of the women. But clearly more research is needed to establish how these results are 'accomplished' in couples' everyday life. Thus, it might be investigated whether and to what extent normative beliefs about 'who deserves what' support such inequalities. Yet another explanation might focus on culturally and socially established expectations. For instance, lower class men might feel social 'obligations' towards spending personal money that they cannot easily circumvent (and might not want to circumvent precisely so as not to endanger their earnings potential through loss of social capital), such as going out with friends (see Wight 1993: $200 \mathrm{ff}$. referring to Scotland), ${ }^{21}$ whereas for women other cultural norms apply. They might more easily find possibilities to refrain from spending money, for instance through restricting themselves more to the sphere of private life at home. Of course, this is not meant to imply that they do so voluntarily; rather that they might feel manifest pressure from their husbands or the more 'silent' pressure exerted by their economic situation. And they might yield to such pressure precisely if they attribute to themselves lower opportunities of contributing to the couples' income due to their lack of education.

By way of conclusion, the importance of the observation that in our analyses education and differences in education turn out to be relevant influences on the internal 'balance' of couples should be emphasized. In a 'knowledge society' education and the long-term prospects it offers concerning income potential, orientation and coping are becoming more important than ever. Our results seem to indicate that its influence also makes itself felt concern-

luctant come from the upper middle and upper classes, which are not covered by our sample.

21 Again, we are not aware of similar findings concerning Germany. Note that also Jan Pahl's (1990:132) observation that men in particular may spend more money on outdoor activities such as drinking and gambling while women tend to stay home may point in the same direction. Of course we do not wish to imply that such activities should always be explained in terms of 'obligations' only. 
ing negotiations in couples and their outcomes, and perhaps more so than the mere fact of who earns how much money at a given time. As women increasingly draw level with men concerning education and are perhaps even going to surpass them, this may result in further changes in the internal balance of couples.

\section{References}

Allmendinger, J. / Ludwig-Mayerhofer, W. / Schneider, W. / Wimbauer, C., 2004: Eigenes Geld - gemeinsames Leben. Zur Bedeutung von Geld in modernen Paarbeziehungen. S. 307-325 in: U. Beck / W. Bonß (eds.), Entgrenzung und Entscheidung. Was ist neu an der Theorie reflexiver Modernisierung? Frankfurt am Main: Suhrkamp.

Baxter, J. / Kane, E.W., 1995: Dependence and Independence: A Cross-National Analysis of Gender Inequality and Gender Attitudes. Gender \& Society 9: 193-215.

Becker, G.S., 1981: A Treatise on the Family. Cambridge, MA: Harvard University Press.

Bianchi, S.M. /Milkie, M.A. / Sayer, L.C. / Robinson, J.P., 2000: Is Anyone Doing the Housework? Trends in the Gender Division of Household Labor. Social Forces 79: 191-228.

Blood, R.O. / Wolfe, D.M., 1960: Husbands and Wives. The Dynamics of Married Living. Glencoe: The Free Press.

Blumstein, P. / Schwartz, P., 1985: American Couples. Money, Work, Sex. New York: Pocket Books.

Brines, J., 1993: The Exchange Value of Housework. Rationality and Society 5:302-340.

Burgoyne, C.B., 1990: Money in Marriage: How Patterns of Allocation both Reflect and Conceal Power. Sociological Review 38: 634-665.

Burgoyne, C.B. /Lewis, A., 1994: Distributive Justice in Marriage: Equality or Equity? Journal of Community and Applied Social Psychology 4: 101-114.

Cheal, D., 1993: Changing Household Financial Strategies: Canadian Couples Today. Human Ecology 21: 197-213.

Edwards, M., 1982: Financial Arrangements made by Husbands and Wives: Findings of a Survey. Australian and New Zealand Journal of Sociology 18: 320-338.

Elizabeth, V., 2001: Managing Money, Managing Coupledom: a Critical Examination of Cohabitants' Money Management Practices. The Sociological Review 49: 389-411.

Employment in Europe, 2004: Recent Trends and Prospects. Brussels: European Commission

Fleming, R., 1997: The Common Purse. Income Sharing in New Zealand Families. Auckland: Auckland University Press.

Giesen, D. / Kalmjin, M., 1997: Samen of apart bankieren? Een onderzoek naar het geldbeheer van gehuwd en ongehuwd samenwonende paren. Mens en Maatschappij 72: 21-39.
Gräbe, S., (ed.) 1998: Vom Umgang mit Geld. Finanzmanagement in Haushalten und Familien. Frankfurt/New York: Campus.

Hayes, B.C. / McAllister, I. / Studlar, D.T., 2000: Gender, Postmaterialism and Feminism in Comparative Perspective. International Political Science Review 21: 425-439.

Jenkins, S.P., 1991: Poverty Measurement and the Withinhousehold Distribution: Agenda for Action. Journal of Social Policy 20: 457-483.

Heisterhagen, T. / Hoffmann, R.-W., 2003: Lehrmeister Währungskrise? Monetäre Schlüsselerfahrungen deutscher Familien in drei Generationen. Wiesbaden: Westdeutscher Verlag.

Ludwig-Mayerhofer, W., 2000: Transaction Costs, Power, and Gender Attitudes in Financial Arrangements of Couples, in: J. Weesie / W. Raub (eds.), The Management of Durable Relations. Amsterdam: ThelaThesis (auf CD-ROM).

McRae, S., 1987: The Allocation of Money in Cross-class Families. Sociological Review 35: 97-127.

Nash, J.C., 1950: The Bargaining Problem. Econometrica 18: $155-162$.

Nyman, C., 1999: Gender Equality in 'the Most Equal Country in the World'? Money and Marriage in Sweden. The Sociological Review 47: 766-793.

Pahl, J., 1983: The Allocation of Money and the Structuring of Inequality within Marriage. Sociological Review 31: 237-262.

Pahl, J., 1989: Money and Marriage. Basingstoke, London: MacMillan.

Pahl, J., 1990: Household Spending, Personal Spending and the Control of Money in Marriage. Sociology 24: 119-138.

Pahl, J., 1995: His Money, Her Money: Recent Research on Financial Organisation in Marriage. Journal of Economic Psychology 16: 361-376.

Potuchek, J.L., 1997: Who Supports the Family? Gender and Breadwinning in Dual-Earner Marriages. Stanford, CA: Stanford University Press.

Roman, C. / Vogler, C., 1999: Managing Money in British and Swedish Households. European Societies 1 (3): 419-456.

Rosendorfer, T., 2000: Kinder und Geld. Gelderziehung in der Familie. Frankfurt/New York: Campus.

Rubery, J. / Smith, M. / Fagan, C., 1999: Women's Employment in Europe: Trends and Prospects. London: Routledge.

Schmedt, A., 2003: Schulden für Andere durch Bürgschaften und Kreditmitunterschriften. Ein frauenspezifisches Problem? S. 139-152 in: B. Wrede (ed.), Geld und Geschlecht. Tabus, Paradoxien, Ideologien. Opladen: Leske + Budrich.

Schneider, W. / Hirseland, A. / Ludwig-Mayerhofer, W. I Allmendinger, J., 2005: Macht und Ohnmacht des Geldes im Privaten - Zur Dynamik von Individualisierung in Paarbeziehungen. Soziale Welt 56: 203-224.

Singh, S., 1997: Marriage Money. The Social Shaping of Money in Marriage and Banking. St Leonards: Allen \& Unwin. 
SOEP Group, 2001: The German Socio-Economic Panel (GSOEP) After More than 15 Years - Overview. Vierteljahrshefte zur Wirtschaftsforschung (E. Holst / D.R. Lillard / T.A. DiPrete (eds.), Proceedings of the 2000 Fourth International Conference of German Socio-Economic Panel Study Users (GSOEP 2000) 70: 7-14.

Stamp, P., 1985: Research Note: Balance of Financial Power in Marriage: an Exploratory Study of Breadwinning Wives. Sociological Review 33: 546-557.

Treas, J., 1993: Money in the Bank: Transaction Costs and the Economic Organization of Marriage. American Sociological Review 58: 723-734.

Vogler, C., 1998: Money in Households: some Underlying Issues of Power. The Sociological Review 46: 687-713.

Vogler, C. / Pahl, J., 1993: Social and Economic Change and the Organisation of Money in Marriage. Work, Employment \& Society 7 (1): 71-95.

Vogler, C. / Pahl, J., 1994: Money, Power and Inequality within Marriage. Sociological Review 42: 263-288.

Vogler, C., 2005: Cohabiting Couples: Rethinking Money in the Household at the Beginning of the Twenty First Century. Sociological Review 53: 1-29.
Wight, D., 1993: Workers not Wasters. Masculine Respectability, Consumption and Employment in Central Scotland. Edinburgh: Edinburgh University Press.

Wilson, G., 1987: Money: Patterns of Responsibility and Irresponsibility in Marriage, in: J. Brannen / G. Wilson (eds.), Give and Take in Families. Studies in Resource Distribution. London: Allen \& Unwin.

Wimbauer, C., 2003: Geld und Liebe. Zur symbolischen Bedeutung von Geld in Paarbeziehungen. Frankfurt/ New York: Campus.

Wimbauer, C. / Schneider, W. / Ludwig-Mayerhofer, W., 2002: Prekäre Balancen - Liebe und Geld in Paarbeziehungen, in: C. Deutschmann (ed.), Leviathan Sonderheft 21: Die gesellschaftliche Macht des Geldes: 263-285.

Wrede, B. (ed.), 2003: Geld und Geschlecht. Tabus, Paradoxien, Ideologien. Opladen: Leske + Budrich.

Young, M., 1952: Distribution of Income within the Family. British Journal of Sociology 3: 305-321.

Autorenvorstellung: Jutta Allmendinger, geb. 1956 in Mannheim, studierte Soziologie und Sozialpsychologie an der Universität Mannheim, danach absolvierte sie ein Graduiertenstudium in Soziologie, Volkswirtschaftslehre und Statistik an der Universität Wisconsin. 1989 promovierte sie an der Harvard University in Cambridge, USA. Von 1988 bis 1991 war Jutta Allmendinger Wissenschaftliche Angestellte am Max-Planck-Institut für Bildungsforschung in Berlin, danach Gastwissenschaftlerin an der Harvard Business School in Cambridge (USA). Seit 1992 ist Jutta Allmendinger Professorin für Soziologie an der Ludwig-Maximilians-Universität München (derzeit beurlaubt). Ihre Habilitation erwarb sie 1993 an der Freien Universität Berlin. Seit Februar 2003 leitet sie das Institut für Arbeitsmarkt- und Berufsforschung der Bundesagentur für Arbeit in Nürnberg. Jutta Allmendinger war Fellow am Center for the Advanced Study in the Behavioral Sciences der Universität Stanford (1996-1997) sowie Vorsitzende der Deutschen Gesellschaft für Soziologie (1999-2002). 2004 wurde sie als ordentliches Mitglied in die Berlin-Brandenburgische Akademie der Wissenschaften berufen, 2005 in den Hochschulrat der TU Darmstadt. Seit 2006 ist sie Mitglied der Wissenschaftlichen Kommission des Wissenschaftsrats.

Wolfgang Ludwig-Mayerhofer, geb. 1954 in München. Studium der Soziologie und Philosophie in München. Promotion und Habilitation in Bielefeld. 1980 bis 1994 Mitarbeit in zahlreichen Forschungsprojekten. 1995 bis 1999 Wissenschaftlicher Angestellter an der Ludwig-Maximilians-Universität München, 1999 bis 2003 Professor für Soziologie an der Universität Leipzig, seit 2003 an der Universität Siegen.

Lehr- und Forschungsschwerpunkte: Sozialwissenschaftliche Forschungsmethoden, Soziale Ungleichheit, Arbeitsmarktpolitik, Familiensoziologie, Soziologie des Lebensverlaufs, Rechtssoziologie.

Zahlreiche Publikationen aus diesen Gebieten. Zuletzt in dieser Zeitschrift: Gleiches (Straf-)Recht für alle? Neue Ergebnisse zur Ungleichbehandlung ausländischer Jugendlicher im Strafrecht der Bundesrepublik (mit Heike Niemann). ZfS 26, 1997: 35-52.

Hermann Gartner, geb. 1968 in Straubing. Dr. oec. publ. Studium der Volkswirtschaftslehre in Regensburg. Promotion an der volkswirtschaftlichen Fakultät der LMU München. Seit Februar 2003 Mitarbeiter am Institut für Arbeitsmarktund Berufsforschung in der Bundesagentur für Arbeit.

Forschungsschwerpunkte: Geschlechtsspezifische Lohnungleichheit, Methoden zur Ergänzung fehlender Werte, Saisonbereinigung von Zeitreihen.

Veröffentlichung: Fakten zur Entwicklung der qualifikatorischen und sektoralen Lohnstruktur. in: Mitteilungen aus der Arbeitsmarkt- und Berufsforschung, Jg. 36, H. 4. S. 493-508, 2003 (mit Lutz Bellmann). In dieser Zeitschrift: Geschlechtsspezifische Lohnunterschiede in Branchen, Berufen und Betrieben (mit Thomas Hinz), ZfS 34, 2005: $22-39$. 